\title{
Oea
}

JURNAL PENDIDIKAN GEOGRAFI

\section{PENERAPAN METODE PENUGASAN UNTUK MENINGKATKAN KEMAMPUAN MEMAHAMI PETA PADA SISWA SEKOLAH DASAR}

\author{
Nana Sutarna \\ STKIP Muhammadiyah Kuningan, email: sutarna_89@yahoo.com
}

\begin{abstract}
This research is based on researcher's concern in the lack of social studies improvement regarding to students' map understanding. This research aims to improve elementary students' ability in understanding map. This research uses qualitative approach with classroom action research method. The research model uses cycle model which covers four components: planning, action, observation, and reflection. The research subjects are 35 fourth grade students of SDN 1 Cengal. The instrument uses quistionare, observation sheet, and field data records. Based on the research can be concluded as follow: first, lesson plan in applying assignment method has its own characteristic compared to another lesson plan method. Second, there is learning development process in each cyclus. Assignment method encourages students to be active in learning and stimulates to improve learning process to be better. Third, the average score in the cyclus I is 70,07, the average score in the cyclus II is 73,83 and the average score in the cyclus III is 82,00. From the explaination above, can be concluded that there is the development in each cyclus which means that assignment method can improve the map understanding ability in elementary students.
\end{abstract}

Keywords: learning, map, assignment method, cycle.

\section{PENDAHULUAN}

IPS merupakan subjek meter dalam dunia pendidikan di negara kita, yang diarahkan bukan hanya kepada pengembangan penguasaan konsep-konsep dasar ilmu sosial, tetapi juga sebagai materi yang dapat mengembangkan komunikasi dan tanggung jawab, baik sebagai individu, sebagai warga masyarakat maupun sebagai warga dunia. Tujuan IPS yang diberikan pada jenjang persekolahan adalah memperkenalkan siswa kepada pengetahuan tentang kehidupan masyarakat manusia secara sistimatis yang dapat mendidik siswa dalam mengembangkan pengetahuan, sikap, dan keterampilan agar dapat mengambil bagian secara aktif dalam kehidupan kelak sebagai anggota masyarakat dan warga negara yang baik.

Sapriya, dkk. (2007, hlm. 39) mengemukakan bahwa: Di dalam kerangka tujuan IPS serta dikaitkan dengan tujuan pendidikan itu sendiri, termasuk di dalamnya misi pembelajaran yang mengacu pada penanaman nilai dan pengembangan sikap yang akhirnya bermuara pada perubahan tingkah laku sebagai warga masyarakat.

Saat ini, proses pembelajaran IPS mengandung sejumlah tantangan yang harus segera ditemukan solusinya. Berbagai kritik dan sekaligus menjadi kelemahan dari pelaksanaan pendidikan IPS lebih banyak bermuara pada aspek metodologi pembelajaran IPS yang lebih bersifat teoretis dan kognitif, termasuk di dalamnya aspek muatan kurikulum IPS dan faktor peserta didik. IPS dianggap hanya ilmu pengetahuan bersifat teoritis dan kering aspek-aspek praktis yang dapat diterapkan. Untuk menepis anggapan tersebut diperlukan terobosan baru dalam mengaplikasikan materi IPS dalam kehidupan keseharian siswa.

Letak suatu tempat dapat dilihat melalui peta. Peta memuat lokasi di permukaan bumi, baik yang berada di daratan maupun di lautan. Pengetahuan 
peta sangatlah penting agar seseorang tidak tersesat dalam mencari suatu lokasi. Dari pengetahuan peta juga dapat diketahui daratan tinggi, daratan rendah, letak perkebunan, jalan darat, dan daerah pegunungan. Dengan demikian ketika seseorang memahami peta dan membawanya pada saat bepergian terutama saat menempuh perjalanan jauh, akan sangat membantu. Selain sebagai penunjuk arah, memiliki pemahaman peta juga sangat membantu ketika ingin mengetahui berbagai kondisi daerah. Dengan memiliki kepandaian membaca peta, seseorang dapat menentukan jarak tempuh dari satu kota ke kota lainnya, yang tentunya sangat bermanfaat untuk berbagai keperluan.

Pada jenjang sekolah dasar kelas IV dalam mata pelajaran Ilmu Pengetahuan Sosial, terdapat materi tentang peta. Ketika berbicara peta, maka dibutuhkan metode pembelajaran yang sesuai untuk mengartikan simbol-simbol dalam peta membutuhkan pengetahuan yang cukup. Oleh karena itu, perlu menggunakan metode pembelajaran yang selaras dengan kebutuhan tersebut. Penelitian ini dilatar belakangi oleh seringnya siswa usia sekolah dasar tersesat. Siswa belum mampu menentukan arah, belum mampu membuat denah rumah dengan baik. Fungsi dari peta sangat penting bagi peserta didik usia SD. Ketika peserta didik mampu membaca dan menginterpretasikan peta, maka sesungguhnya ada beberapa kemampuan yang dipahami, meliputi kemampuan mengembangkan pemahaman tentang: (1) gejala alam dan kehidupan; (2) menerapkan pola berpikir keruangan dalam memahami gejala alam dan kehidupan manusia; (3) mengembangkan keterampilan mengelola sumber daya dan kesejahteraan; (4) berempati dalam membangun pola interaksi dan beradaptasi dengan lingkungan alam, sosial, dan budaya; dan (5) menumbuhkan kesadaran terhadap perubahan lingkungan, dan cinta tanah air. (Depdiknas, 2002; 2003). Dengan demikian, secara konseptual, materi peta pada jenjang sekolah dasar bertujuan untuk mengembangkan "kompetensi keruangan/ spasial" atau "keterampilan geografi", dan "kesadaran keruangan/spasial" atau "kesadaran geografis". Secara umum kemampuan spasial terdiri dari kemampuan: (1) ruang geografis, yang berkaitan dengan pemetaan (tempat, lokasi, daerah, dsb); dan (2) ruang historis, yang berkaitan dengan tempat, lokasi, daerah dalam suatu peristiwa bersejarah atau peninggalan-peninggalan bersejarah; (3) ruang ekonomis, yang berkaitan dengan tempat, lokasi, daerah terjadinya berbagai aktivitas ekonomi; (4) ruang budaya, yang berkaitan dengan tempat, lokasi, daerah budaya lokal, nasional, dan internasional; dan ruang sosial, yang berkaitan dengan interaksi sosial antar manusia dalam konteks keruangan (Farisi, 2005).

Metode penugasan disumsikan dapat menjadi jalan keluar bagi permasalahan tersebut. Metode ini sangat cocok diberikan untuk mengimbangi bahan pelajaran yang sangat banyak sementara waktu sedikit. Syaiful Bahri Djamarah dan Aswan Zain (1995, hlm. 96) mengatakan bahwa "metode tugas adalah cara penyajian bahan dimana guru memberikan tugas tertentu agar bisa melakukan kegiatan belajar". Masalah tugas yang dilakukan oleh siswa dapat dilakukan di dalam kelas, halaman sekolah di perpustakaan, di bengkel, di Laboratorium, di rumah siswa atau dimana saja asal tugas itu dapat dikerjakan.

Menurut sagala (2005, hlm. 219) metode penugasan adalah: Cara penyajian bahan pelajaran dimana guru memberikan tugas tertentu agar murid melakukan kegiatan belajar, kemudian harus dipertanggung jawabkan. Tugas yang diberikan guru dapat memperdalam bahan pelajaran dan dapat pula mengecek bahan yang telah dipelajari. Tugas merangsang anak untuk aktif belajar baik secara individu maupun kelompok.

Pupuh Fathurrohman (2010, hlm. 64) mengatakan metode penugasan tidak sama 
dengan pekerjaan rumah, tetapi jauh lebih luas dari itu. Tugas yang dapat diberikan kepada anak didik ada berbagai jenis, karena itu tugas sangat banyak macamnya, tergantung pada tujuan yang akan dicapai, seperti tugas meneliti, menyusun laporan (lisan/tulisan), tugas di laboratorium dan lain-lain.

Berdasarkan pemaparan yang telah dikemukakan, maka untuk permasalahan di atas harus ada solusi. Salah satu solusi yang dapat dilakukan oleh guru untuk meningkatkan kemampuan memahami peta adalah perlunya penerapan proses pembelajaran yang baik dengan pembelajaran aktif. Berkaitan dengan hal ini, maka peneliti melaksanakan suatu penelitian yang berjudul "Penerapan Metode Penugasan untuk Meningkatkan Kemampuan Memahami Peta Pada Peserta didik di Sekolah Dasar". Tujuan dari penelitian ini adalah untuk: (1) Mengetahui perencanaan pembelajaran dengan menggunakan metode penugasan dalam pembelajaran IPS mengenai memahami peta pada siswa Kelas IV Sekolah dasar. (2) Mengetahui pelaksanaan pembelajaran dengan menggunakan metode penugasan dalam pembelajaran IPS mengenai memahami peta pada siswa Kelas IV Sekolah Dasar. (3) Mengetahui peningkatan kemampuan siswa dalam memahami peta pada pembelajaran IPS yang menggunakan metode penugasan di Kelas IV Sekolah Dasar.

\section{METODE PENELITIAN}

Penelitian yang dilakukan menggunakan pendekatan kualitatif. Metode yang digunakan dalam penelitian ini adalah metode penelitian tindakan kelas. Dasar pertimbangan digunakannya metode ini adalah pendapat yang dikatakan Moleong (2004, hlm. 5) bahwa, Pertama menyesuaikan metode kualitatif lebih mudah apabila berhadapan dengan kenyataan ganda. Kedua metode ini menyajikan secara langsung hakikat hubungan antara peneliti dan responden. Ketiga metode ini lebih peka dan lebih dapat menyesuaikan diri dengan banyak penajaman pengaruh bersama dan terhadap nilai yang dihadapi.

Bogdan dan Taylor (Moleong 2004, hlm. 3) menyatakan bahwa, Metodologi Kualitatif sebagai prosedur penelitian yang menghasilkan data deskriptif berupa katakata tertulis atau lisan dari orang-orang dan perilaku yang dapat diamati. Pendekatan ini diarahkan pada latar dan individu tersebut secara holistik (utuh). Jadi dalam hal ini tidak boleh mengisolasikan individu atau organisasi kedalam variabel atau hipotesis, tetapi perlu memandangnya sebagai bagian dari suatu keutuhan. Desain penelitian yang digunakan mengacu pada bentuk desain bercorak Penelitian Tindakan Kelas (classroom action research), sehingga model penelitian yang digunakan adalah model daur (siklus) yang mencakup empat komponen, yaitu : rencana (Planning), observasi (observation), tindakan (action), dan refleksi (reflection).

Penjelasan dari bagan (gambar 1) adalah sebagai berikut :

Tahap 1 : Menyusun Rancangan Tindakan (Planning). Dalam tahapan ini peneliti menjelaskan tentang apa, mengapa, kapan, dimana,oleh siapa dan bagaimanatindakan tersebut dilakukan. Penelitian tindakan yang ideal sebetulnya dilakukan secara berpasangan antara pihak yang melakukan tindakan dengan pihak yang mengamati proses jalannya tindakan. Istilah untuk cara iniadalah penelitian kolaborasi, pihak yang melakukan tindakan adalah guru itu sendiri, sedangkan yang diminta melakukan pengamatan adalah peneliti. Pelaksana guru peneliti adalah pihak yang paling berkepentingan untuk meningkatkan kinerja, maka pemilihan strategi pembelajaran disesuaikan dengan selera dan kepentingan guru peneliti, agar pelaksanaan tindakan dapat terjadi secara wajar, realistis, dan dapat dikelola dengan mudahnya.

Tahap 2 : Pelaksanaan Tindakan (Acting). Pada tahap ini adalah pelaksanaan yang 
merupakan implementtasi atau penerapan isi rancangan, yaitu mengenakan tindakan di kelas. Hal yang perlu diingat adalah bahwa dalam tahapan ke-2 ini guru harus ingat dan berusaha mentaati apa yang harus dirumuskan dalam rancangan, dan harus pula berlaku wajar, tidak dibuatbuat. Dalam refleksi, keterkaitan antara pelaksanaan dengan perencanan perlu diperhatikan secara seksama agar sinkron dengan maksud semula.

Tahap 3 : Pengamatan (Observation). Pada kegiatan pengamatan yang dilakukan oleh pengamat. Sebetulnya kurang tepat apabila pengamatan ini dipisahkan dengan pelaksanaan tindakan, karena seharusnya pengamatan dilakukan pada waktu yang sama.

Tahap 4 : Refleksi (Reflecting). Pada tahap ini merupakan kegiatan untuk mengemukakan kembali apa yang sudah dilakukan. Kegiatan refleksi ini sangat tepat dilakukan ketika guru pelaksana sudah selesai melakukan tindakan, kemudian berhadapan dengan peneliti untuk mendiskusikan implementasi rancangan kegiatan.

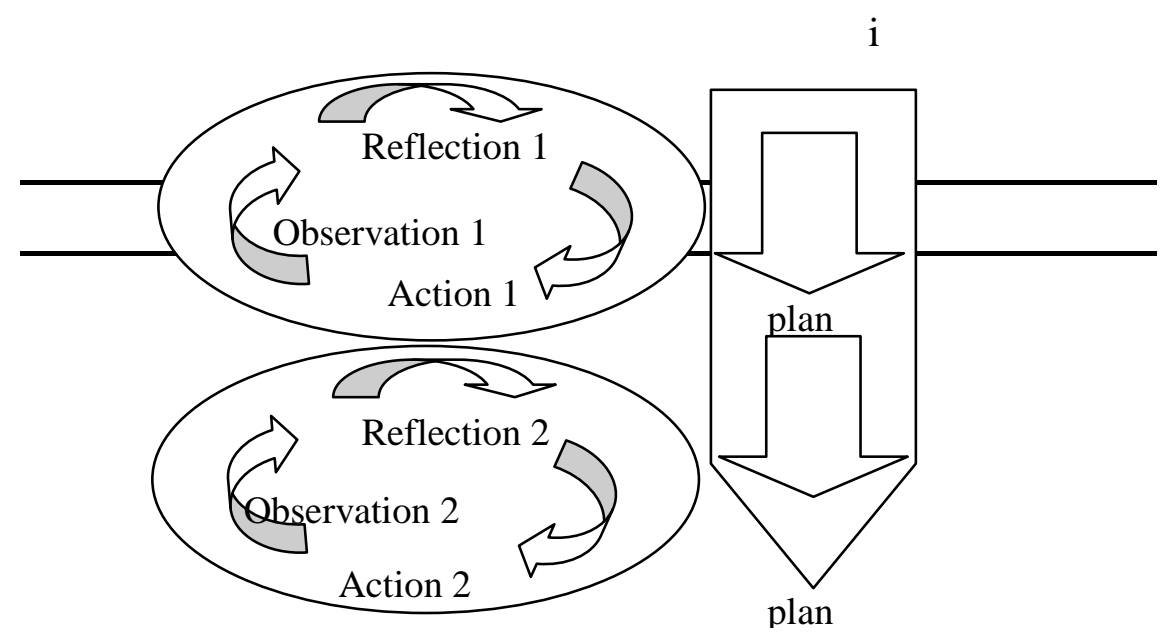

Gambar 1 Spiral Kemmis dan Taggart (Wiraatmaja, 2005, hlm. 66)

Penelitian ini dilakukan di SDN 1 Cengal yang terletak di Desa Cengal Kecamatan Japara Kabupaten Kuningan. Adapun subjek penelitian adalah siswasiswi kelas 4 yang berjumlah 35 orang, yang terdiri dari 13 siswa laki-laki dan 22 siswa perempuan.

Instrumen yang digunakan dalam penelitian adalah (1) Lembar tes. Lembar tes yang dibuat adalah untuk mengetahui ketercapaian proses pembelajaran yang dilakukan. Ada beberapa jenis lembar tes penilaian diantaranya lembar penilaian untuk mengamati pelaksanaan kegiatan guru dan siswa pada pembelajaran IPS, lembar penilaian proses pembelajaran, lembar penilaian akhir pembelajaran dan lembar penilaian rekapitulasi penggabungan dari penilaian proses pembelajaran dan penilaian akhir pembelajaran sebagai hasil dalam pemahaman siswa terhadap materi membaca peta lingkungan setempat melalui metode penugasan. (2) Lembar observasi. Lembar observasi yang dibuat adalah untuk mengetahui aktivitas yang dilakukan oleh guru dan siswa pada waktu melakukan metode penugasan dengan menggunakan format lembar observasi. (3) Catatan Lapangan. Catatan lapangan yaitu catatan kegiatan selama pelaksanaan berlangsung yang terjadi didalam kelas yang berisi deskripsi proses dan hasil pembelajaran, interpretasi, analisa, dan saran dari peneliti terhadap praktikan atau rekan sejawat. Berkaitan dengan istilah catatan lapangan, Bogdan dan Biklen (Moleong 2005:209) menyatakan bahwa "Catatan lapangan adalah catatan yang tertulis tentang apa yang didengar, dilihat, dan diperkirakan dalam rangka pengum- 
pulan data dan refleksi terhadap data dalam penelitian kualitatif". Catatan lapangan digunakan untuk memperoleh data kongkrit berbentuk catatan kualitatif yang terjadi dalam pembelajaran dengan format catatan lapangan.

\section{HASIL DAN PEMBAHASAN}

Berdasarkan deskripsi, analisis dan refleksi setiap siklus penelitian yang dilakukan, peneliti dapat menyimpulkan bahwa terdapat beberapa temuan esensial dalam penelitian yang telah dilaksanakan. Temuan-temuan esensial tersebut, merupakan hasil terpenting dari penelitian yang dilaksanakan. Temuan-temuan esensial yang peneliti peroleh secara rinci diuraikan sebagai berikut.

\section{Perencanaan Pembelajaran Metode Penugasan}

Jika dilihat dari perencanaan pembelajaran, umumnya RPP metode penugasan sama dengan RPP metode pembelajaran lain. Namun, terdapat kekhasan pada bagian kegiatan inti pembelajaran. Metode penugasan, siswa menjadi lebih aktif karena mereka merasakan langsung proses pembelajaran. Ini senada dengan apa yang sampaikan dalam buku panduan Depdikbud (1993, hlm. 154) bahwa guru dalam pelaksanaan kegiatan pembelajaran hendaknya menerapkan prinsip-prinsip belajar aktif, yaitu pembelajaran yang melibatkan siswa baik secara fisik, mental (pemikiran dan perasaan) dan sosial, serta sesuai dengan tingkat perkembangan siswa. Pembelajaran merupakan satu kesatuan dari dua kegiatan yang searah. Kegiatan belajar berpusat pada siswa, sedang kegiatan mengajar berfokus pada guru. Pada metode penugasan, LKS (sebagai acuan dalam kegiatan pembelajaran) didalamnya terdapat langkahlangkah pembelajaran yang disesuaikan dengan jenis tugas yang diberikan. Langkah-langkah ini menjadi pedoman bagi siswa (kelompok) dalam mengerjakan tugas. Ini sejalan dengan pendapat yang diungkapkan Nana Sudjana (1987, hlm. 81) bahwa ada beberapa langkah-langkah yang harus diikuti dalam memberikan penggunaan metode tugas yaitu "tujuan yang akan dicapai harus jelas, jenis tugas yang jelas dan tepat sehingga anak mengerti apa yang ditugaskan tersebut, tugas yang diberikan sesuai dengan kemampuan siswa dan ada petunjuk/sumber yang dapat membantu pekerjaan siswa".

Dari paparan diatas, ada hal-hal yang harus diperhatikan oleh guru/pelaksana tindakan dalam membuat perencanaan pembelajaran (RPP) dan LKS. Tugas yang diberikan harus jelas disertai dengan petunjuk yang memadai. Dalam penelitian ini dibuat tiga Rencana Pelaksanaan Pembelajaran (RPP) yang diaplikasikan dalam 3 siklus. Perbedaan ketiga RPP yang dibuat dalam penelitian ini adalah sebagai berikut:

Perencanaan pada siklus I berisi rencana tugas untuk membuat peta provinsi Jawa Barat dengan teknik pembesaran. LKS yang dibuat berisi langkah-langkah yang harus diikuti siswa dalam membuat peta dengan teknik ini.

Perencanaan pada siklus II berisi rencana tugas untuk membuat denah rumah masing-masing disertai skala sederhana dan arah mata angin. LKS yang dibuat berisi langkah-langkah pembuatan denah dan cara menghapalkan serta mengaplikasikan arah mata angin. Pada siklus II, guru memberikan tugas untuk dikerjakan oleh siswa di rumah.

Perencanaan pada siklus III berisi rencana tugas memahami dan membuat simbol kenampakan alam dan simbol pusat kota/administratif untuk menemununjukkan suatu lokasi. Tugas pada siklus III sikerjakan di kelas dengan menggunakan tes unjuk kerja sebagai evaluasi akhir untuk mengukur kemampuan siswa dalam memahami peta.

Dari ketiga perencanaan pembelajaran yang dibuat, perencanaan pembelajaran pada siklus III merupakan yang terbaik untuk mengukur kemampuan siswa dalam 
memahami peta. Selain itu, tes unjuk kerja yang diterapkan dapat menjadi nilai lebih dalam mengetahui kemampuan sesungguhnya setiap siswa dan membuat guru lebih obyektif dalam memberikan penilaian. Metode penugasan memberi keleluasaan kepada guru untuk merencanakan dan melaksanaan pembelajaran termasuk menentukan tempat bagi anak dalam mengerjakan tugas, tidak terpaku hanya di dalam kelas.

\section{Proses Pembelajaran Metode Penugasan}

Proses pembelajaran yang terjadi pada siklus I pertemuan pertama berjalan kurang baik. Pada pertemuan pertama, siswa yang diberikan tugas menggambar peta provinsi Jawa Barat dengan teknik pembesaran untuk dikerjakan secara individu. Hanya sekitar $23 \%$ siswa yang dapat menyelesaikan tugas yang diberikan sampai batas waktu yang ditetapkan. Proses pembelajaran pada siklus 1 pertemuan kedua berjalan lebih baik. Dalam prosesnya, metode penugasan diberikan kepada siswa secara berkelompok. Hampir semua kelompok dapat menyelesaikan tugasnya.

Proses pembelajaran pada siklus II baik itu pertemuan pertama maupun pertemuan kedua berjalan cukup baik. Dalam prosesnya, guru kembali mengelompokkan siswa dalam kegiatan pembelajarannya. Ada hal yang berbeda antara siklus I dan siklus II, yakni penerapan metode penugasannya. Pada siklus I guru memberikan tugas kepada siswa untuk dikerjakan di kelas, namun pada siklus II guru mencoba alternatif lain untuk memberikan tugas kepada siswa agar dikerjakan di rumah.

Pada siklus III pertemuan pertama masih menggunakan pengelompokkan siswa dalam pembelajarannya. Pemberian tugas pada siklus III kembali dilakukan di kelas, ini dilakukan untuk mengukur obyektifitas kemampuan individual siswa karena dari hasil analisis siklus II terindikasi ada siswa yang mengerjakan tugasnya dibantu secara langsung oleh orang-orang terdekatnya. Pada siklus III pertemuan kedua guru melakukan tes unjuk kerja sebagai alternatif pengukuran kemampuan siswa dalam membaca dan memahami peta secara keseluruhan.

\section{Peningkatan Kemampuan Siswa dalam Memahami Peta}

Perolehan nilai rata-rata pada siklus I adalah 70,07, dengan nilai rata-rata pertemuan pertama sebesar 63,17 dan tindakan 2 sebesar 72,17. Pada pertemuan pertama beberapa siswa mengalami kesulitan dikarenakan tugas yang diberikan harus dikerjakan secara individu. Peningkatan hasil yang cukup signifikasn terlihat pada hasil pertemuan pertama setelah guru memodifikasi proses pembelajaran. Pada tindakan 2 tugas yang diberikan dikerjakan secara kelompok. Kesimpulan dari siklus I, jika dipersentase maka keberhasilan proses pembelajaran hanya $70 \%$.

Perolehan nilai rata-rata pada siklus II adalah 73,83, dengan nilai rata-rata pertemuan pertama sebesar 72,54 dan tindakan 2 sebesar 75,11. Jika dilihat, terdapat peningkatan hasil yang cukup signifikan apabila dibandingkan dengan siklus I. Baik itu pertemuan pertama maupun pertemuan kedua pada siklus II, penugasan yang diberikan kepada siswa bukan dikerjakan di kelas, namun di rumah. Meski terdapat indikasi beberapa siswa melakukan manipulasi tugas, namun hal ini dapat dilakukan sebagai salah satu alternatif bagi guru. Kesimpulan dari siklus II, jika dipersentase maka keberhasilan proses pembelajaran hanya $74 \%$.

Perolehan nilai rata-rata pada siklus III adalah 82,00, dengan nilai rata-rata pertemuan pertama sebesar 79,71 dan pertemuan kedua sebesar 84,29. Pada siklus III penugasan dilaksanakan di kelas, ini dilakukan sebagai refleksi hasil analisis siklus II bahwa ada indikasi manipulasi tugas jika tugas tersebut dikerjakan di rumah. Kesimpulan dari siklus III, jika dipersentase maka keberhasilan proses pembelajaran hanya $82 \%$. 
Dari ketiga siklus yang dilakukan, terdapat peningkatan cukup signifikan pada setiap siklusnya. Peningkatan keberhasilan proses dan hasil pembelajaran merupakan indikasi bahwa metode penugasan merupakan salah satu metode yang dapat digunakan untuk meningkatkan kemampuan siswa dalam memahami peta.

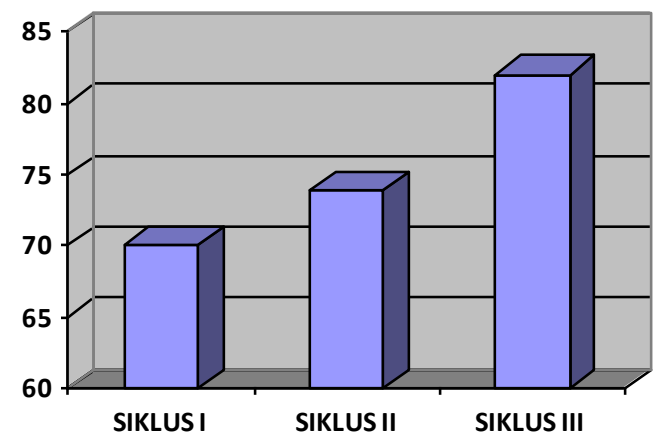

Gambar 2 Grafik Nilai Rata-rata Individu Per Siklus

Berdasarkan temuan-temuan esensial yang dikemukakan pada bagian pembahasan, maka peneliti dapat melakukan sintesis dan konfirmasi terhadap hasil temuan esensial tersebut, berkaitan dengan kajian teoritis yang telah diuraikan. Peneliti berpendapat bahwa materi tentang peta merupakan salah satu pokok bahasan terpenting dalam pembelajaran IPS di sekolah dasar. Ini diperkuat dengan pendapat yang dikemukakan Hermawan et. al. (2007, hlm. 102) mengemukakan bahwa "IPS di sekolah dasar bertujuan untuk mengembangkan pengetahuan, nilai, sikap dan keterampilan siswa tentang masyarakat, bangsa dan Negara Indonesia". Untuk mampu mengembangkan hal-hal tersebut, langkah pertama adalah siswa mengenal daerahanya sendiri (kecamatan, kabupaten/kota dan provinsi) hingga akhirnya siswa mampu menerapkan kemampuaannya secara global. Untuk dapat membaca dan memahami peta, ada beberapa indikator yang harus dikuasai. Menurut Winarti (2008, hlm. 16) beberapa hal yang perlu diketahui dalam membaca peta : 1) Isi peta dan tempat yang digambarkan, melalui judul; 2) Lokasi daerah; 3) Arah, melalui petunjuk arah (orientasi); 4) Jarak atau luas suatu tempat dilapangan melalui skala peta; 5) Kenampakan alam, misalnya relief, pegunungan/gunung, lembah/sungai, jaringan lalu lintas, persebaran kota. Kenampakan alam ini dapat diketahui melalui simbol-simbol peta dan keterangan peta (legenda).

Peneliti mengangkat metode penugasan dikarenakan keterbatasan alokasi waktu (jam pelajaran IPS) di kelas IV sekolah dasar. Dalam panduan kurikulum Tingkat Satuan Pendidikan (KTSP), alokasi waktu pelajaran IPS hanya 3 (tiga) jam pelajaran per minggu. Hal ini dirasa tidak seimbang dengan banyaknya materi yang harus disampaikan kepada para siswa, apalagi jika berbicara masalah peta, perlu adanya variasi baru dalam pembelajaran. Dalam proses pembelajaran guru melaksanakan kegiatan yang telah direncanakan untuk mencapai tujuan yang telah ditetapkan. Pendapat tersebut juga didukung oleh Syaiful Bahri Djamalah dan Aswan Zain (1995, hlm. 53) yang mengatakan bahwa metode mengajar adalah strategi pengajaran sebagai alat untuk mencapai tujuan yang diharapkan. Dengan metode penugasan, siswa menjadi lebih aktif karena mereka merasakan langsung proses pembelajaran. Ini senada dengan apa yang sampaikan dalam buku panduan Depdikbud (1993, hlm. 154) bahwa guru dalam pelaksanaan kegiatan pembelajaran hendaknya menerapkan prinsip-prinsip belajar aktif, yaitu pembelajaran yang melibatkan siswa baik secara fisik, mental (pemikiran dan perasaan) dan sosial, serta sesuai dengan tingkat perkembangan siswa. Pembelajaran merupakan satu kesatuan dari dua kegiatan yang searah. Kegiatan belajar berpusat pada siswa, sedang kegiatan mengajar berfokus pada guru. Senada dengan itu, Roestiyah (2001, hlm. 133) pemberian penugasan biasanya digunakan dengan tujuan: Agar siswa memiliki hasil belajar yang lebih mantap, 
karena siswa melaksanakan latihan-latihan selama melakukan tugas sehingga pengalaman siswa dalam mempelajari sesuatu dapat lebih terintegrasi. Hal itu terjadi disebabkan siswa mendalami situasi atau pengalaman yang berbeda, waktu menghadapi masalah-masalah baru. Disamping itu untuk memperoleh pengetahuan, cara melaksanakan tugas akan memperluas dan memperkaya pengetahuan serta keterampilan siswa di sekolah atau di lingkungan sekolah itu. Dengan kegiatan melaksanakan tugas, siswa aktif belajar dan merasa terangsang untuk meningkatkan pembelajaran menjadi lebih baik. Memupuk inisiatif dan berani bertanggung jawab sendiri. Banyak tugas yang harus dikerjakan siswa, hal itu diharapkan mampu menyadarkan siswa untuk selalu memanfaatkan waktu senggangnya untuk hal-hal yang menujang belajarnya dengan mengisi kegiatankegiatan yang berguna dan konstruktif.

Dari pendapat di atas, dapat disimpukan bahwa tujuan dari memberikan penugasan kepada siswa adalah untuk menjadikan siswa belajar lebih mantap, menjadi pengalaman baru buat siswa dalam mempelajari sesuatu dapat lebih terintegrasi, memperkaya pengetahuan serta keterampilan siswa di sekolah sehingga dapat memupuk inisiatif dan berani bertanggung jawab sendiri.

Alokasi waktu sikus I tindakan 1 adalah 2 jam pelajaran (70 menit), dengan ketersediaan waktu yang cukup, peneliti dan pelaksana tindakan (guru) membuat perencanaan bahwa penugasan yang diberikan pada siswa dikerjakan secara individu. Namun dilihat dari proses dan hasil pembelajaran kurang sesuai harapan. Lebih dari setengah jumlah siswa tidak dapat menyelesaikan tugas yang diberikan. Setelah melakukan analisis dan refleksi, kami bersepakat pada tindakan 2 akan membagi siswa dalam beberapa kelompok untuk mempermudah siswa menyelesaikan tugas/pekerjaan yang diberikan. Menurut sagala (2005, hlm. 219) metode penugasan adalah: Cara penyajian bahan pelajaran dimana guru memberikan tugas tertentu agar murid melakukan kegiatan belajar, kemudian harus dipertanggung jawabkan. Tugas yang diberikan guru dapat memperdalam bahan pelajaran dan dapat pula mengecek bahan yang telah dipelajari. Tugas merangsang anak untuk aktif belajar baik secara individu maupun kelompok.

Dari paparan di atas dapat disimpulkan bahwa penerapan metode penugasan dapat dilakukan secara individu maupun kelompok, tergantung dengan keadaan di kelas dan keefektifan dari hasil yang nantinya didapat. Metode penugasan juga dapat merangsang siswa untuk aktif belajar dikarenakan siswa merasakan sendiri proses pembelajarannya.

Proses pemberian tugas pada pertemuan 1 dan 2 siklus II dilakukan di rumah. Variasi ini dilakukan untuk membandingkan hasil penerapan metode penugasan pada siklus I dan diharapkan adanya perubahan ke arah yang lebih baik baik secara proses maupun hasil. Ini sejalan dengan yang dikemukakan Aswan Zain (1995, hlm. 96) bahwa, tugas yang dilakukan oleh siswa dapat dilakukan di dalam kelas, halaman sekolah di perpustakaan, di bengkel, di Laboratorium, di rumah siswa atau dimana saja asal tugas itu dapat dikerjakan. Pendapat diatas mengindikasikan bahwa penugasan tidak hanya dapat dilakukan di dalam kelas namun dapat diterapkan sesuai kondisi dan situasi dan ada yang tentunya dapat menunjang keberhasilan pembelajaran. Menurut Nana Sudjana (1987, hlm. 81), ada beberapa hal yang perlu diperhatikan dalam pemberian tugas kepada siswa, yakni : (1) tujuan yang akan dicapai; (2) jenis tugas yang jelas dan tepat sehingga anak mengerti apa yang ditugaskan tersebut; (3) sesuai dengan kemampuan siswa; (4) ada petunjuk/sumber yang dapat membantu pekerjaan siswa; dan (5) sediakan waktu yang cukup untuk mengerjakan tugas tersebut. 
Jika dilihat dari hasil, ada peningkatan yang signifikan antara siklus I dan siklus II, ini membuktikan bahwa tugas yang diberikan di rumah memberi hasil yang lebih positif dibanding dengan tugas yang diberikan di kelas. Namun ada indikasi beberapa siswa yang meminta bantuan orang-orang terdekatnya dalam mengerjakan tugas, ini merupakan salah satu kelemahan dari metode penugasan. Sesuai dengan pendapat Sagala (2005, hlm. 219), jika penugasan tersebut dilakukan di rumah, hal yang mungkin terjadi adalah seringkali siswa melakukan penipuan diri, mereka hanya meniru hasil pekerjaan orang lain, tanpa mengalami peritiwa belajar dan adakalanya tugas itu dikerjakan oleh orang lain jika tanpa pengawasan.

Pada siklus III, penugasan kembali dilakukan di kelas dengan menggunakan pembelajaran secara berkelompok. Ini dilakukan untuk meemperbaiki proses dan hasil siklus II yang diindikasikan ada tugas yang dikerjakan bukan oleh siswa. Pada tindakan 2 tes yang dilakukan dengan unjuk kerja, sebagai akumulasi pengukuran kemampuan siswa dalam membaca dan memahami peta secara individu. Terdapat peningkatan yang signifikan antara siklus II dan siklus III. Keberhasilan penggunaan metode penugasan untuk meningkatkan kemampuan siswa memahami peta, didukung juga oleh perolehan nilai ratarata hasil tes setiap tindakan yang relatif meningkat. Peningkatan yang terjadi pada tiap siklus membuktikan bahwa metode penugasan dapat meningkatkan kemampuan siswa dalam memahami peta.

\section{SIMPULAN}

Berdasar pada hasil penelitian maka simpulan penelitiannya sebagai berikut:

Pertama Perencanaan pembelajaran dalam menerapkan metode penugasan memiliki kekhasan tersendiri dibanding dengan perencanaan metode pembelajaran lain. Dalam RPP yang dibuat, terdapat LKS yang berisi langkah-langkah bagi siswa dalam mengerjakan tugas. Pada bagian kegiatan inti pembelajaran, ada beberapa hal yang harus diperhatikan yaitu: tujuan yang akan dicapai harus jelas, jenis tugas yang jelas dan tepat sehingga siswa mengerti apa yang ditugaskan tersebut, tugas yang diberikan sesuai dengan kemampuan siswa dan ada petunjuk/ sumber yang dapat membantu pekerjaan siswa.

Kedua Dari paparan diatas, ada hal-hal yang harus diperhatikan oleh guru/ pelaksana tindakan dalam membuat perencanaan pembelajaran (RPP) dan LKS. Tugas yang diberikan harus jelas disertai dengan petunjuk yang memadai. Petunjuk inilah yang menjadi pedoman siswa dalam mengerjakan tugas. Dilihat dari prosesnya, pembelajaran pada siklus I berjalan kurang baik, sebagian besar siswa belum dapat menyelesaikan tugas yang diberikan karena keterbatasan waktu dan kurangnya kekompakkan antara anggota kelompok. Proses pembelajaran pada siklus II berjalan cukup baik. Ada variasi lain yang diterapkan pada siklus II yakni tugas diberikan oleh guru untuk dikerjakan di rumah.ini dilakukan untuk membandingkan proses dan hasil pembelajaran dengan siklus sebelumnya. Proses pembelajaran pada siklus III berjalan baik. Tugas yang diberikan pada siklus III kembali dikerjakan di kelas. Hal ini berdasar pada hasil refleksi siklus II yang menelaah kelemahan ketika tugas diberikan untuk dikerjakan di rumah.

Ketiga Kemampuan siswa dalam memahami peta meningkat. Ini dibuktikan dengan indikator bahwa siswa dapat memahami judul peta, mampu menentukan arah mata angin, menemununjukkan) lokasi daerah/tempat, mampu menentukan skala dan jarak serta mampu mengartikan simbol kenampakkan alam (pegunumgan, lembah, sungai, danau, jaringan lalu lintas dan persebaran kota).

Berdasarkan simpulan penelitian, maka penulis memberikan beberapa rekomendasi yaitu sebagai berikut: 1) Bagi para akademisi yang ingin meningkatkan 
kemampuan membaca peta siswa sekolah dasar, metode penugasan merupakan salah satu metode alternatif yang dapat dipergunakan; 2) Kepada guru untuk selalu senantiasa menggali pengetahuan dan mengembangkan keterampilan dalam mengajar sehingga dapat memberikan pembelajaran yang terbaik untuk siswasiswinya; 3) Kepada kepala sekolah untuk selalu memberikan memotivasi serta arahan kepada para guru untuk selalu meningkatkan kualitas pembelajaran dengan cara mengembangkan metodemetode pembelajaran yang ada. Salah satunya yaitu metode penugasan untuk diterapkan dalam pembelajaran IPS.

\section{DAFTAR PUSTAKA}

Depdikbud,(1993). Petunjuk pemilihan dan pembuatan alat peraga. Jakarta.

Depdiknas. (2002). Kurikulum Berbasis Kompetensi. Jakarta: Pusbangkurrandik, Depdiknas.

Djamarah, Syaiful dan Aswan Zain. (1995). Strategi Belajar Mengajar.Jakarta: Rineka Cipta.

Farisi, M.I. (2005). Rekonstruksi Dasardasar Pemikiran Pendidikan IPS-SD Berdasarkan Perspektif Konstruktivisme.
Disertasi. tidak diterbitkan. Bandung: UPI.

Fathurrohman, Pupuh. (2010). Strategi Belajar Mengajar. Bandung: Refika Aditama

Hermawan, AH. Dkk. (2007). Belajar dan Pembelajaran SD. Bandung: UPI PRESS

Meleong, Lexi. (2004). Metode Penelitian Kualitatif. Bandung: PT. Remaja Rosdakarya.

Moedjono(1992:2). Strategi Pembelajaran. Jakarta: Proyek Pembinaan Tenaga Kependidikan Dirjen Dep.Dikti.

Roestiyah, N.k. (2001). Strategi Belajar Mengajar. Cetakan keenam. Jakarta: PT Rineka Cipta.

Sagala, S.(2005). Konsep dan Makna Pembelajaran untuk Membantu dan Memecahkan Problematika Belajar dan Mengajar. Bandung: Alfabeta.

Sapriya, dkk. (2007). Pembelajaran dan evaluasi hasil belajar IPS. Bandung: UPI PRESS.

Sudjana, Nana. (1987). Dasar-Dasar Proses Belajar Mengajar. Bandung : Sinar Baru

Winarti. (2008). Peta, Atlas, Globe. Klaten: Cempaka Putih

Wiriaatmadja, Rochiati. (2005). Metode Penelitian Tindakan Kelas. Bandung: Angkasa. 